\title{
The Theoretical Framework and Application Frontier of Socioemotional Wealth Theory: A Literature Review from the Perspective of Family Firm
}

\author{
Jingwen Wu \\ School of Management, Jinan University, Guangzhou, China \\ Email: wujingwen827@gmail.com
}

How to cite this paper: $\mathrm{Wu}, \mathrm{J} . \mathrm{W}$. (2018) The Theoretical Framework and Application Frontier of Socioemotional Wealth Theory: A Literature Review from the Perspective of Family Firm. Modern Economy, 9, 190-202.

https://doi.org/10.4236/me.2018.91012

Received: December 27, 2017

Accepted: January 21, 2018

Published: January 24, 2018

Copyright $\odot 2018$ by author and Scientific Research Publishing Inc. This work is licensed under the Creative Commons Attribution International License (CC BY 4.0).

http://creativecommons.org/licenses/by/4.0/ (c) (i) Open Access

\begin{abstract}
For decades, family firms have received high attention from the society, especially from academy community. However, researches on family firms had been relying on other subject's theories and frameworks in the absence of its own unique theory system. Finally, in 2007, Gomez-Mejia and other scholars put forward a brand new theory-Socioemotional Wealth Theory (SEW). The appearance of the new theory enabled people to set up a framework of interpretation. Nowadays, as the new theory entirely fits in with the features and situations of family firms, it has gradually become a dominant interpretation framework in the field, providing a new perspective for study. We hope that, through analyzing and summarizing the existing researches on Socioemotional Wealth Theory, including its rising up, content and constitutional dimensions, measurement, and factors that influence the decisions and preferences of family firms, this article could provide some references for subsequent discussion and study.
\end{abstract}

\section{Keywords}

Family Firm, Socioemotional Wealth, Transgenerational Succession, Strategic Decision

\section{Introduction}

Family firm is a distinctive kind of organizational form that combines family system and modern business organization, which leads to notable differences compared with non-family firm. Family holdings and co-governance of family 
members are important features of family firm. US scholar Chandler defined family firm as "Founders and their closest partners (and families) take hold of the major ownership. They remain close relationship with the managers and reserves decision-making power on senior management, especially the decision right on financial policy, resource distribution and selection of senior staff' [1]. This classic definition emphasized that the shares are owned and controlled by a family.

Since the reform and opening up, our nation has been vigorously developing socialist market economy. Focusing on the central task of economic construction, we have shaped the pattern with the public sector remaining dominant and diverse sectors of the economy developing side by side. During this period, private economy gradually became an important part of national economy. As a majority part of private economy, family firms also developed rapidly on its own superiority and have been playing a vital role in every industry.

As a result, family firms have received attention from the society, especially from academy community. More and more scholars hope to deepen the research by establishing relative theories and frameworks. However, at the beginning, researches on family firms had been relying on other subject's theories and frameworks in the absence of its own unique theory system. Until Socioemotional Wealth Theory (SEW) was put forward, researches on family firms were able to establish theory and framework of interpretation that is entirely based on its own characteristic and situation. Domestic researches on family firms and social discussion have been going on. Against the backdrop, this article aims to systematically introduce the framework and application status of SEW Theory. We hope that, through analyzing and summarizing the existing researches on SEW theory, including its rising up, content and constitutional dimensions, measurement, and factors that influence the decisions and preferences of family firms, this article could provide some references for subsequent discussion and study.

In order to get a better understanding of the main content of this article, we would like to introduce the structure of this article before you read it. At the beginning of this article, we analyze the research background of SEW theory and the reasons for its rising up. Then we describe the theoretical framework and measure dimensions of SEW in detail. Further, we sum up the empirical researches on SEW in family firms, such as their preference for different dimensions of SEW, corporate governance, transgenerational succession, and decisionmaking behaviors. Finally, we put forward the defects of present researches and future directions of the SEW theory.

Although we have tried to systemically analyze and summarize the development and application of the SEW theory, we may still miss some important literatures due to the limited access to comprehensive information. However, we hope this article to be able to provide a new direction for further study in this field and to make breakthroughs on research of SEW theory in family firms. 


\section{The Rise of Socioemotional Wealth Theory}

Family firm is the most common type of organization with a long history around the world [2]. In recent decades, it has been receiving growing attention and frequently studied by scholars from all nations.

But during the early researches, there had not been a framework of interpretation and vision that fitted in well with its particulars. Most of the scholars borrowed from other scientific fields, such as agency theory, stewardship theory, truism, and stakeholder theory. It is conceivable that due to some uniqueness of family firms, some of assumptions in these "borrowed" theories were unable to satisfy the researches on family firms. Furthermore, these theories may itself contradict each other, resulting in those unconvincing results.

Based on the study need, scholars thought it necessary to put forward an original theory to explain the features of family firms. Therefore, in 2007, Gomez-Mejia and other scholars put forward a brand new theory-Socioemotional Wealth Theory (SEW). The appearance of the new theory enabled people to set up a framework of interpretation that entirely fitted in with the features and situations of family firms. According to SEW theory, the reason why family firms differ from non-family firms is that certain noneconomic factors involving the family are taken as chief reference factors in decision-making, while non-family firms make decisions based on economic factors. In other words, family members of family firm pursue not only economic goals but also the family's noneconomic goals out of family vision, and consequently making decisions that do not conform to rational economic decisions.

In accordance with Gomez-Mejia's definition, SEW covers various forms, such as identity of family members, social influence of family members, family succession, continuation of family values and preservation of family social capital and so on. Though the theory is merely a fundamental framework of family firm research without in-depth content, the theory points out a new direction for further study, and gradually becomes a dominant interpretation framework in the field. With the development of the researches, more and more family firm behaviors come into scholars' sight. They found that SEW has quite apparent explanation power on these behaviors. Certainly, out of the procedure, certain potential limitations of SEW have also drawn attention from researchers and even incurred some criticism. Yet this is a necessary stage that a theory grows from immature to mature.

\section{Constitutional Dimensions and Measurement of SEW}

\subsection{Constitutional Dimensions of SEW}

In 2007, Gomez-Mejia and other scholars put forward a brand new theory in family firm studies-Socioemotional Wealth (SEW). In the theory, SEW refers to the emotional benefits that result from the achievement of noneconomic goals centred on the family. As a result, family members will consider the gains and losses of SEW as a chief reference factor [3]. Some scholars also believed that the 
pursuit of noneconomic goals, i.e. the willingness to preserve or increase SEW, was the most significant difference between family firms and non-family firms [4]. In spite of the fact that all firms will pursue noneconomic goals, these family-centred goals are given a higher priority in family firms [5].

When SEW theory began to form up, the division of its dimensions was quite general and unclear. Yet from the present studies, SEW has covered such a large area that it can be called as an "umbrella concept".

At the beginning, Gomez-Mejia and other scholars divided SEW into three dimensions of emotion, cultural values and altruism. However, Berrone and other scholars (2012) argued that the division from Gomez-Mejia could not fully reflect the rich meaning and content of SEW [6]. Consequently, they introduced a detailed division, dividing it into five dimensions (also called as FIBER): 1) Family control and influence; 2) Identification of family members with the firm; 3) Binding social ties; 4) Emotional attachment of family members; 5) Renewal of family bonds to the firm through dynastic succession.

The first dimension is family control and influence. Aiming to preserve SEW, family firms tend to put family control and influence first, though this may cause adverse effect on corporate performance. This is reflected by their directly or indirectly affecting firm management and strategic decisions through appointing chairman of the board, CEO or other senior managers based on their ownership, social status or personal charm of family members.

The second dimension is identification of the family members with the firm. Normally a family firm will integrate its family name into the firm brand, where the firm will be considered as the extension of the family itself. Out of strong identification of family members with the firm and the integration of firm honor and family honor, family members therefore are more willing to promote family reputation and image through favourable social responsibility performance.

The third dimension is binding social ties. Family members extend their mutual benefits from blood or marriage relationships within the family to nonfamily employees of the firm and non-family partnerships outside the firm or even the society that the firm locates in.

The fourth dimension is emotional attachment of family members. Lots of scholars believe that, originating from the involvement of family, the emotional factor inter-weaved with business factor is a distinguishing feature of family firm. As a result of the blurring limits between family and firm, family emotions penetrate into the organization, influencing the decision-making. At the same time, when the firm is growing, the emotional attachment become stronger and stronger. This dimension is quite useful in understanding family members' altruism under certain circumstances.

The fifth dimension is renewal of family bonds to the firm through dynastic succession. Transgenerational succession can be considered as the core content of SEW. From the perspective of family owners, the firm is not only an equity of the family, but also symbolize the renewal and succession of the family. There- 
fore, family members would consider the firm as a long investment owned by the family and will be passed to descendants. This type of SEW have also led to the long-term oriented investment behaviors.

The division from Berrone's team was approved and adopted by many scholars, yet some other scholars argued that some problems existed with it, such as overlapping relationship, inconformity of standard of division (some divisions based on caused while some divisions based on results) and so on.

In view of the above defects, Miller and Breton-Miller (2014) redivided SEW into two categories according to its impact on the stakeholders: restricted SEW and extended SEW [7]. According to Miller and Breton-Miller, restricted SEW gives rise to family member's attention on matters with short-term interest and that the interest between the firm and non-family stakeholders could be violated. Consequently, it is short-term strategic oriented. On the contrary, extended SEW causes the family members to focus more on the family's long-term development. Meanwhile it leads them to pay attention to the interest of all stakeholders. So, it is long-term strategic oriented. This is a kind of SEW that attached more importance to family honor and is beneficial to the sustainable development of the firm.

On the basis of most of the present study results, SEW tends to be wholly interpreted as positive effects that the family acquired from the firm. And it is considered as a kind of motivation factor that positively affected the firm. Recently, scholars like Kellermanns put forward an idea in a review article that "dark side" could exist in SEW. They pointed out that the family going after SEW could become an emotional load on some of the family members, (i.e. transgenerational succession and family control) and they may in turn cause the firm to adopt some behaviors that could damage the interest of other stakeholders [8]. For this hypothesis, Dou's team is the first to respond with evidence. Through research on the charitable donation of family firms in China, they have verified the existence of dark side to some extend.

To sum up, so far scholars' recognition of SEW' constitutional dimensions still follows previous study results around non-economic goals and family influence. And the division mainly centres on the effects that the firm can bring to varied stakeholders. With the development of theory and empirical researches, scholars are having a more comprehensive and deeper understanding of the constitutional dimensions of SEW and the impacts that various dimensions could have on family firms. However, there are still some problems about the detailed division and measurement that require our further studies. It is suggested that follow-up studies test the constitutional dimensions independently under specific conditions, so as to strengthen our in-depth knowledge of how family's participation could affect behaviors in family firms.

\subsection{Measurement of SEW}

On the other hand, most of the scholars adopted the proportion of family's 
ownership as the measurement way of SEW. This measurement implies that family's SEW is positively correlated with the proportion of ownership. The logic is that the higher the proportion of ownership, the larger effect that a family could have on the firm's strategic decisions, the stronger the identification of family members with the firm and the emotional attachment of family members. However, different families with a same proportion of ownership often have significant differences on emotion, relationship and culture values, therefore resulting in different SEW [6]. To cover this deficiency, one possible way is to seek other proxy variables for robustness test on the basis of theoretical analysis. According to the content of SEW, in addition to the proportion of ownership, family's management involvement and transgenerational involvement can also be the proxy variables.

Zellweger et al. (2012) adopted the difference between the acceptable selling price and market value of family firm as the measurement way of SEW [9], which originated from the study of Zellweger and Astrachan on "emotional value of owning a firm" in 2008 [10]. It is based on the logic that: family owners would quote at a price that is higher than the market value when selling the firm, in order to compensate for the losses of SEW. They also found that the intention for transgenerational control of family firm had obviously positive correlation with the price they can accept. It can be seen that this measurement method can accurately measure SEW. While considering SEW is a psychological evaluation derived from family members, the use of monetary price to reflect SEW is also unconvincing.

In addition, developing a direct psychometric method to measure SEW may be the most accurate measurement way of SEW. However, psychometric method also has its defects: the psychometric result reflects individual attitudes or feelings, while SEW is defined by the whole family. Moreover, the result of psychological measurement is likely to be affected by the social desirability effect, which may easily lead to deviation.

\section{Empirical Researches on SEW Theory}

As the SEW Theory is powerful in explaining the behaviors of family firms, such as corporate governance, transgenerational succession and decision-making, it has attracted more and more scholars' attention. As a result, the related empirical researches start to introduce the concept of SEW more and more frequently.

\subsection{Family Firms' Preference for Different Dimensions of SEW}

When talks about family firms' preference for different dimensions of SEW, Gomez-Mejia (2014) found that family menbers attached great importance to the dimension of "family control and influence" from the view of finance [11]. To achieve this goal, family members may varnish their financial statement. That is to say, family firms are more willing to adjust the earning rather than disclose their accounting information. Contrarily, if family firms give priority to the di- 
mension of "Identification of family members with the firm", they prefer to disclose their accounting information for fear that family reputation and image may suffer from great losses due to sham accounting statement.

From the view of life cycle, Miller and other scholars (2013) drew a conclusion that family owners and managers' priority of each dimension of SEW was different at different stages [12]. At the start-up stage of a family firm, founders are usually younger, lack of credit, customers, funds, and so on. Therefore, the critical task at this stage is to maintain the survival of their firms, which leads to their preference for behaviors that are short-term oriented and centred on the family. With the continuous development of the family firm, family owners often have stronger emotional attachment to their firm and family, which is another dimension of the SEW.

Similarly, Strike and Berrone (2015) took a research about the relationship between the tenure of $\mathrm{CEO}$ and their preference for different dimensions of SEW [13]. They demonstrated that the priority of SEW dimensions can change within a family firm depending on the CEO's time to retirement. When there is still a long time for a CEO to retire, he will give priority to the dimension of "family control" and will be not willing to engage in international acquisitions, which may lead to the loss of the company's control. International expansion means that family firm will be more dependent on non-family members, such as bond holders and non-family managers, which will weaken the SEW of the family. However, the CEO who approaches retirement will pay more attention to the inheritance of his family. Therefore, he will value the dimension of "transgenerational succession" more than other dimensions in SEW.

\subsection{Socioemotional Wealth and Corporate Governance}

SEW mainly affects family firms' governance mode through family relationships, which are mainly reflected in family executives' tenure and compensation.

According to the research by Gomez-Mejia and other scholars (2001) on family firms in Spain, it is demonstrated that the tenure of family CEOs was usually longer than that of non-family CEOs, even if family firms were facing high risk of failure [14]. Similarly, McConaughy (2000) also found that the tenure of family executives were about three times more than that of non-family executives [15].

However, family executives are usually paid less than non-family executives, and the compensation of family executives are also less associated with their performance. After investigating 47 family CEOs and 35 non-family CEOs, McConaughy (2000) found that the compensation of family CEO was lower than that of non-family CEO, especially the incentive compensation [15]. Meanwhile, Gomez-Mejia et al. (2003) used the data from 253 listed family firms in 19951998, founding that family identity had a significant negative impact on executive compensation, and the concentration of family ownership was negatively correlated with the compensation of family CEO [16]. Cruz's (2010) research 
showed that the variable income of family executive was not related to corporate performance [17], though family and non-family executives had the same variable income ratio, which meant that non-family executives were more likely to be accountable for poor corporate performance while family executives were usually free from punishment.

We can acquire a reasonable explanation to the above phenomena based on the SEW theory. According to Gomez-Mejia (2011), family executive is not only the business manager but also the representative of family as an owner to the company. On the one hand, as a representative of the family owners, family executive must fulfill family obligations to preserve the SEW of their family. On the other hand, in order to provide occupational security for family executive, family directors usually attribute the poor performance to uncontrollable factors such as luck and environment rather than the ability of family executive. Therefore, family executive can gain some "psychological rewards" in family firms (e.g. a sense of occupational security) and is willing to accept lower compensation, compared with non-family executive. There are some related researches to support this conclusion, as well. For example, with the increase of industry risk, family owners often provide higher compensation for family CEO to compensate for the occupational risk that the family CEO may face as a result of an enterprise failure [16]. That is to say, there is a negative correlation between the compensation of the family CEO and the sense of occupational security [18]. Also, compared with non-family CEO, family $\mathrm{CEO}$ is more willing to cut their pay in the family firm with stronger managerial control. And their compensation will increase with the decline in family control.

\subsection{Socioemotional Wealth and Transgenerational Succession}

Research on the transgenerational succession from SEW-based view can better explain why family firms prefer internal succession. According to SEW theory, as internal succession can keep the continuous control to the firms, as well as provide a strong guarantee for family preservation and creation of their SEW. At the same time, it will keep family reputation and image along with the generation of the family firm. In other words, family can gain significant noneconomic benefits (so-called SEW) from internal succession, which is an important reason for their preference for choosing internal succession.

Family firms usually train their successors in a different way, compared with non-family firms. Often, non-family firms tend to outsource their successor training, while family firms pay more attention to individualized guidance and training (especially developing the relationships between the present leaders and the successors, as well as the relationships between the stakeholders and the successors), which is an ideal way to guarantee the transgenerational succession of heterogeneity knowledge of the family (e.g. family value and culture) and an effective way to cultivate successors' sense of corporate identity and enhance their emotional attachment of family firms. All of the actions above will be good for 
the preservation of their SEW.

Furthermore, compared with non-family firms, family firms are more unacceptable in dealing with the problem of introducing professional management. Family owners believe that professional management will weaken the family's control over business decisions. In addition, as family owners do not know enough about non-family managers, it may lead to uncertainty about managers' behaviors [17]. If an external expert with special knowledge is hired and the family owners are not familiar with the knowledge, it may aggravate the problem of information asymmetry between the two parties [3]. All of the above result in the losses of family SEW, which is something that they do not expect to see.

\subsection{The Influence of SEW on Decision-Making of Family Firms}

Conventional wisdom suggests that family owners are usually risk-averse, as they concentrate most of their fortune in a firm. Once the risks are encountered in their firms, their welfare will be seriously affected [19] [20]. According to SEW theory, the gains and losses of SEW will be considered as a chief reference factor when family members making decisions. Family owners tend to undertake business risk when they face the potential losses of SEW, as they believe that the business risks are under control or they are over optimistic about the future of their firms. And the losses of SEW are not permitted in their eyes. As a result, between the two, they prefer to choose the former. Of course, out of consideration of protecting family SEW, family owners will not allow their firm to take too much risks. Therefore, once they face the threat of survival, the survival of their firm will become the chief reference factor for the family owners to make decisions. Chrisman and Patel (2012) also found that the family owners would think more about the sustainability and survival of their firm when the business performance was lower than what they expected [21]. That is to say, family owners are not always risk-averse or risk-prefer. Instead, sometimes they may be risk-averse, and sometimes they may be risk-preferred, which mainly depends on the nature of the risk that the family firm faces.

In a groundbreaking research, Gomez-Mejia and other scholars (2007) made an empirical study on 1237 family owned olive oil Milis from 1944 to 1998 in Spanish who faced the choice of becoming a member of a cooperative, a decision associated with the loss of family control but lower business risk, or remaining indepent, which preserved the family's SEW but greatly increased its performance hazard. They found that family firms preferred "family control" and would rather give up a series of economic benefits (e.g. competitive advantage, scale advantage, tax benefits, technical support, financing channel and so on) from becoming a member of a cooperative, compared with non-family firms [22]. Thus, when family firms make decisions, the gain and loss of SEW is a more important reference factor than the economic gain and loss. Therefore, they may deviate from the goal of economic efficiency in order to preserve or increase their SEW. Later, these scholars continued to make further researches 
on the strategic behaviors of diversification and $\mathrm{R} \& \mathrm{D}$ investment in family firms based on SEW theory. To avoid the dilution of corporate control caused by the entry of external resources and managers, family owners are usually unwilling to invest in R \& D and diversification [23]. To them, it will help them to keep the control of family firms and keep the independence and autonomy of their firms.

Take R \& D investment of family firms for example, Gomez-Mejia and other scholars (2011) found that the conservative attitude of family firms to R \& D investment was not because of the high-risk aversion to $\mathrm{R} \& \mathrm{D}$ activities, instead, they considered that R \& D activities may result in the losses of family SEW [3]. To them, a large amount of money may be needed to support the R \& D activities, which will lead to the dilution of their control of the firms. Also, external creditors will restrict the business of family firms. All of these will lead to the losses of SEW, which are unacceptable for family members. From this point of view, family firms usually inhibit R \& D investment to preserve their SEW [24] [25].

Chrisman and Patel (2012) respectively studied the R \& D investment behaviors of family firms in different situations, founding that the level of R \& D investment of family firms would be higher than that of non-family firms when family firms felt the threat of survival or the willing of transgenerational succession. Chrisman and Patel (2012) also concluded that the level of R \& D investment would be higher when the next generation entered senior management [21]. This may be based on the willing of transgenerational succession, in other words, the willing of protecting or increasing their SEW. Zhu et al. (2016) demonstraded that different dimensions of SEW had different effects on R \& D investment of family firms, measuring SEW of family firms through questionnaires. Yan et al. (2014) also found that different SEW had different effects on $\mathrm{R}$ \& D investment, based on different level of family ownership and management.

In recent years, some scholars attempted to integrate SEW theory and other theoretical perspectives to test and explain the behaviors in family firms. Berrone and other scholars (2010) firstly analyzed and tested the performance of family firms and non-family firms about environmental pollution based on both SEW theory and the corporate reputation theory. Through this research, they found that family firms paid more attention to the firm and the family's reputation, compared with the non-family firms [26]. Therefore, they would take the initiative in reducing the environment pollution. Furthermore, Cennamo et al. (2012) expanded the scope of concern to the stakeholders. They pointed out that as the SEW became the chief reference factor in strategic decisions, they would give more consideration to the interests of different stakeholders [27]. In addition, they found that the preference of different dimensions of SEW would affect their attitudes towards internal and external stakeholders.

Through the collection and analysis of existing literatures, we can find that the existing researches basically follow the basic interpretation logic proposed by 
Gomez-Mejia in 2007. That is, family involvement will lead to the willing of preserving and increasing family SEW. And then it will push them to influence the strategic decisions of family firm. However, at present, the studies of family firms based on SEW theory are mainly concerned with several types of behaviors which have higher impacts on the corporate finance directly. For those behaviors which have lower financial impacts on family firms are less concerned. So, this may be a new direction for further study.

\section{Defects of Present Researches and Future Directions}

Nowadays, SEW theory presents a new study framework for the research field of family firms. Furthermore, scholars have made breakthroughs on research of determinations when family firms' operation off their target. However, as the SEW theory is a brand new research perspective to the scholars, present literatures are needed to make further study.

Firstly, we need to tease out the relationships and effects among different dimensions in SEW. SEW is a multi-dimensional concept. These days, most of literatures define SEW as a broad concept, which leads to veil the factors and corporation governance differences among different dimensions in SEW. With the development of the study, explicitly understanding the mechanism of SEW and teasing out the elements in the theory are more and more important. In future study, scholars should test the effects on the corporate behavior and relationship in every dimension in the SEW.

Secondly, scholars need to pay efforts to determine the measurement method of every dimension in SEW. At present, literatures use proxy variable to measure the SEW, which is needed to be further studied cause the relationship between proxy variable and aspiration to preserve the SEW is suspensive. Family involvement provides the legality and ability for the family to affect the firms' strategic behaviors. However, the aspiration to preserve the SEW would aggregate the influences on the behaviors. The combination of these two factors is sufficient condition to affect the firms' behaviors. The absence of one of the factors does bring the deviation of the research results (De Massis, Chirico, Kotlar and Naldi, 2013). Based on the definition on the elements of SEW, scholars need to develop authoritative scale to directly measure the aspiration of SEW preservation. This may be the most fundamental and critical task to promote the development of SEW framework.

At last, current literatures ignore that external environment and SEW are the key factors to influence family firms' determination and governance. Current researches suggest that family's motivation to preserve and create SEW are restrained by their external mechanism to some extent. However, studies on the common influence and mechanism of external environment and SEW to the family firms are still absence. Therefore, to understand the SEW effect under the different mechanism would help us to enrich the related studies and give suggestions to the development of family firms. 


\section{References}

[1] Chandler Jr., A.D. (1977) The Visible Hand: The Managerial Revolution in American Business. Harvard Belknap, Cambridge.

[2] La Porta, R., Lopez-de-Silanes, F. and Shleifer, A. (1999) Corporate Ownership around the World. Journal of Finance, 54, 471-517.

https://doi.org/10.1111/0022-1082.00115

[3] Gomez-Mejia, L.R., Cruz, C., Berrone, P., et al. (2011) The Bind That Ties: Socioemotional Wealth Preservation in Family Firms. Academy of Management Annals, 5, 653-707. https://doi.org/10.1080/19416520.2011.593320

[4] Chrisman, J.J., Chua, J.H., Pearson, A.W. and Barnett, T. (2012) Family Involvement, Family Influence and Family Centered Non-Economic Goals in Small Firms. Entrepreneurship Theory and Practice, 36, 267-293. https://doi.org/10.1111/j.1540-6520.2010.00407.x

[5] Carney, M. (2005) Corporate Governance and Competitive Advantage in Family-Controlled Firms. Entrepreneurship Theory and Practice, 29, 249-265. https://doi.org/10.1111/j.1540-6520.2005.00081.x

[6] Berrone, P., Cruz, C. and Gomez-Mejia, L.R. (2012) Socioemotional Wealth in Family Firms: Theoretical Dimensions, Assessment Approaches, and Agenda for Future Research. Family Business Review, 25, 258-279. https://doi.org/10.1177/0894486511435355

[7] Miller, D. and Breton Miller, L. (2014) Deconstructing Socioemotional Wealth. Entrepreneurship Theory and Practice, 38. https://doi.org/10.1111/etap.12111

[8] Kellermanns, F.W., Eddleston, K.A. and Zellweger, T.M. (2012) Extending the Socioemotional Wealth Perspective: A Look at the Dark Side. Entrepreneurship Theory and Practice, 36, 1175-1182. https://doi.org/10.1111/j.1540-6520.2012.00544.x

[9] Zellweger, T.M., Kellermanns, F.W., Chrisman, J.J., et al. (2012) Family Control and Family Firm Valuation by Family CEOs: The Importance of Intentions for Transgenerational Control. Organization Science, 23, 851-868. https://doi.org/10.1287/orsc.1110.0665

[10] Zellweger, T.M. and Astrachan, J.H. (2008) On the Emotional Value of Owning a Firm. Family Bussiness Review, 21, 347-363. https://doi.org/10.1177/08944865080210040106

[11] Gomez-Mejia, L.R., Campbell, J.T., Martin, G., Hoskisson, R.E., Makri, M. and Sirmon, D.G. (2014) Socioemotional Wealth as a Mixed Gamble: Revisiting Family Firm R \& D Investments with the Behavioral Agency Model. Entrepreneurship Theory and Practice, 38, 1351-1374.

[12] Breton Miller, L. and Miller, D. (2013) Socioemotional Wealth across the Family Firm Life Cycly: A Commentary on "Family Business Survival and the Role of Boards”. Entrepreneurship Theory and Practice, 37, 1391-1397. https://doi.org/10.1111/etap.12072

[13] Strike, V.M., Berrone, P., Sapp, S.G., et al. (2015) A Socioemotional Wealth Approach to CEO Career Horizons in Family Firms. Journal of Management Studies, 52, 555-583. https://doi.org/10.1111/joms.12123

[14] Gomez-Mejia, L.R., et al. (2001) The Role of Family Ties in Agency Contracts. Academy of Management Journal, 44, 81-95. https://doi.org/10.2307/3069338

[15] McConaughy, D.L. (2000) Family CEOs vs. Non-Family CEOs in the Family-Controlled Firm: An Examination of the Level and Sensitivity of Pay to Perfor- 
mance. Family Business Review, 13, 121-131.

https://doi.org/10.1111/j.1741-6248.2000.00121.x

[16] Gomez-Mejia, L.R., et al. (2003) The Determinants of Executive Compensation in Family-Controlled Public Corporations. Academy of Management Journal, 46, 226-237. https://doi.org/10.2307/30040616

[17] Cruz, C., et al. (2010) Perceptions of Benevolence and the Design of Agency Contracts: CEO-TMT Relationships in Family Firms. Academy of Management Journal, 53, 69-89. https://doi.org/10.5465/AMJ.2010.48036975

[18] Combs, J.G., et al. (2010) The Impact of Family Representation on CEO Compensation. Entrepreneurship Theory and Practice, 34, 1125-1144. https://doi.org/10.1111/j.1540-6520.2010.00417.x

[19] Mishra, C.S. and McConaughy, D.L. (1999) Founding Family Control and Capital Structure: The Risk of Loss of Control and the Aversion to Debt. Entrepreneurship Theory and Practice, 23, 53-64. https://doi.org/10.1177/104225879902300404

[20] McConaughy, D.L., et al. (2001) Founding Family-Controlled Firms: Efficiency, Risk and Value. Journal of Small Business Management, 39, 31-49. https://doi.org/10.1111/0447-2778.00004

[21] Chrisman, J.J. and Patel, P.C. (2012) Variations in R \& D Investments of Family and Non-Family Firms: Behavioral Agency and Myopic Loss Aversion Perspectives. Academy of Management Journal, 55, 976-997. https://doi.org/10.5465/amj.2011.0211

[22] Gomez-Mejia, L.R., Haynes, K., Nunez-Nickel, M., et al. (2007) Socioemotional Wealth and Business Risk in Family Controlled Firms: Evidence from Spanish Olive Oil Mills. Administrative Science Quarterly, 52, 106-137. https://doi.org/10.2189/asqu.52.1.106

[23] Gomez-Mejia, L.R., Makri, M. and Kintana, M.L. (2010) Diversification Decisions in Family-Controlled Firms. Journal of Management Studies, 47, 223-252. https://doi.org/10.1111/j.1467-6486.2009.00889.x

[24] Gudmundson, D., Tower, C.B. and Hartman, E.A. (2003) Innovation in Small Businesses: Culture and Ownership Structure Do Matter. Journal of Developmental Entrepreneurship, 8, 1-17.

[25] Short, J.C., Payne, G.T., Brigham, K.H., et al. (2009) Family Firms and Entrepreneurial Orientation in Publicly Traded Firms: A Comparative Analysis of the S \& P 500. Family Business Review, 22, 9-24. https://doi.org/10.1177/0894486508327823

[26] Berrone, P., et al. (2010) Socioemotional Wealth and Corporate Responses to Institutional Pressures: Do Family-Controlled Firms Pollute Less? Administrative Science Quarterly, 55, 82-113. https://doi.org/10.2189/asqu.2010.55.1.82

[27] Cennamo, C., et al. (2012) Socioemotional Wealth and Proactive Stakeholder Engagement: Why Family-Controlled Firms Care More about Their Stakeholders. Entrepreneurship Theory and Practice, 36, 1153-1173.

https://doi.org/10.1111/j.1540-6520.2012.00543.x 